\title{
Nutritional Assessment of Wheat Biscuits and Fortified Wheat Biscuits with Citrus Peels Powders
}

\author{
Hanan M. K. E. Youssef ${ }^{1, *}$, Rasha M. A. Mousa ${ }^{2}$ \\ ${ }^{1}$ Food Science \& Technology Department, Faculty of Agriculture, Ain Shams University Egypt \\ ${ }^{2}$ Home Economic Department, Faculty of Specific Education,Assiut University Egypt
}

\begin{abstract}
Citrus peels, the waste by-products of citrus juices factories are reckoned valuable healthful functional food. The present investigation performed to assess nutritional status of wheat and fortified biscuits with citrus peels powders. Study included determination of gross chemical composition, caloric value, minerals ( $\mathrm{Fe}, \mathrm{Mn}, \mathrm{Cu}, \mathrm{Ca}, \mathrm{Mg}, \mathrm{Na}, \mathrm{K}$ and $\mathrm{P}$ ) of wheat and fortified biscuits with citrus peels powders. Likewise physical and sensory characteristics of control and $10 \%$ fortified wheat biscuits with the four studied citrus peels powders: Tangerine peel powder, Abo-Sora peel powder, Baladi orange peel powder, and Baladi lemon peel powder. The data revealed that $10 \%$ incorporation of citrus peels powders in wheat biscuits increased crude protein, crude fat contents as well as crude fiber, moisture contents and caloric value. However, it decreased carbohydrate content. The supplementation of control biscuits with $10 \%$ citrus peels powders of the four studied citrus enhanced the nutritive value. The data revealed that all $10 \%$ fortified biscuits with the four studied citrus peels powders improved all studied sensory characteristics in all the studied biscuits. Moreover, biscuits fortified with $10 \%$ citrus peel powders. Could be recommended for caloric reduced diets for obese, over-weight persons and diabetic persons.
\end{abstract}

Keywords Wheat biscuit, 10\%, citrus peel powder fortified biscuits, proximate composition, mineral, physical, sensory characteristics, caloric value

\section{Introduction}

It is note-worthy to clarify that citrus peels: the waste by-product of the citrus factories are reckoned as a valuable functional food. So, citrus peels may provide a health benefit beyond the traditional nutrients they contain, as well as prevent diet-related diseases, e.g. metabolic syndrome, type II diabetes, coronary heat disease, obesity, hypertension, certain types of cancer, gastrointestinal diseases and osteoporosis (Block et al., 1992); Steinmetz and Potter (1996); Donalson (2004); and Youssef (2007).

On the other hand, pectin found in highest concentration in segment membrane of citrus fruits appears to be able to prevent prostate and other cancers by acting as mediator in cell communication, a factor known to reduce the likelihood of abnormal cell growth. Sour fruits as lemon appear to have the greatest effect (Liu et al., 2001) and Sugimura (2002).

Furthermore, the dietary fibers are the indigestible, fibrous part of citrus fruits are an essential part of our diet. Because of their water retaining properties, fibers help food pass through the gut faster and therefore have a laxative effect.

Fibers add bulk to the diet and fill up, making less likely to snack on fatty foods. Therefore, we need to eat fibers every

* Corresponding author:

hanankamaly@yahoo.com (Hanan M. K. E. Youssef)

Published online at http://journal.sapub.org/fph

Copyright (C) 2012 Scientific \& Academic Publishing. All Rights Reserved day as part of a balanced diet (Youssef, 2007).

Moreover, pectins, the fiber in citrus peel are fermented in the intestines, producing short-chain fatty acids that prevent the growth of harmful bacteria. They also nourish the cells of the intestinal lining, making them more resistant to becoming cancerous (Donalson, 2004).

Furthermore, we can get soluble fibers from citrus peels, namely from oranges and grape fruit (Bobroff, 2002) and de Vries (2004). Archibald (2005) outlined the beneficial physiological role of dietary fiber in laxation, blood cholesterol and blood glucose attenuation.

Sulamyn et al. (1990) reported the effect of different methods of extraction on the physico-chemical properties of Egyptian summer orange peel oils. Haggag (1992) carried out a pharmacognostical study of citrus aurantifolia swingle and citrus limonia osbeck (family: Rutaceae). She reported that the galactouronic acid content of lime pectin was higher than that of lemon pectin. Eisa (1995) studying the composition of lemon and mandarin peel essential oils and their utilization as anti-pathogenic bacteria agents found that mandarin and lemon peels contained $0.59 \%$ and $0.40 \%$ volatile oil; respectively. Mandarin peel oil was characterized by the presence of high concentration of gamma -terpinene, while lemon peel oil was identified by the presence of beta-pinene, geranyl acetate and methyl cinnamate.

Kamel (1990) studied the effect of gamma irradiation on the total soluble solids, titratable acidity, vitamin $\mathrm{C}$, total sugars, total free amino acids, total carotenoids, total phenols 
and volatile peel oil of navel and Valencia orange fruits. Abdel-Rauf (1997) carried out a study on the production and evaluation of some citrus low terpenes essential oils. Aumar (1997) studied the biochemical components of the essential oils of Balady orange and mandarin. Abdel-Galil (1998) carried out a study on the physicochemical properties of certain citrus peel volatile oils.

El-Shemy et al. (1990) reported the relation between irradiation doses and browning oxidative enzymes and phenol of grapefruits. The phenolic compounds and volatile oils of grapefruits were evaluated. Cohen et al. (1984) studied the characteristics of Israeli citrus peel and citrus juice, namely: the composition of orange juice, grapefruit juice, orange peel and grapefruit peel.

Gonzalez-Molina et al. (2010) reported the natural bioactive compounds of citrus lemon for food and health.

Patil et al. (2010) studied the impact of citrus limonoids on human health and demonstrated that citrus bioactive compounds, such as limonoids, had synergistic effects in preventing certain types of cancers and cardiovascular diseases.

This investigation was designed to produce fortified wheat biscuits with citrus peel powder, which has better nutritional value, available and relatively cheap and does not require any preparation efforts before using. The objective of this investigation was to study the gross chemical composition, caloric value, the mineral composition as well as physical characteristics and sensory quality attributes of wheat biscuits and wheat biscuits fortified with citrus peels powders.

\section{Materials and Methods}

\subsection{Materials}

$5 \mathrm{~kg}$ wheat flour $72 \%$ extraction hard red winter were obtained from El-Haram Milling Company, Faesal, Giza in January 2011. Sugar powder, corn oil, sodium chloride, ammonium bicarbonate, and rose oil were purchased from Assiut local market in January 2011. $20 \mathrm{~kg}$ of each of the four studied citrus fruits were procured from Assiut University horticulture farm, namely: Baladi orange, Abo-Sora orange, Tangerine and Baladi lemon in January 2011.

The citrus fruits were peeled and the obtained peels were sun dried to complete dryness on wood trays. The dried peels were milled by hammer mill to produce citrus peels powders. The citrus peel powder was kept in glass containers at $4^{\circ} \mathrm{C}$ in the refrigerator till the analysis.

\subsection{Technological Process}

\subsubsection{Biscuit Formula and Ingredients}

Control biscuit dough was prepared according to the formula presented in table (1), (Saba, 1997). The supplemented biscuits with citrus peels powders were prepared using the same formula except for replacing the wheat flour with $10 \%$ of each of the four studied citrus peels powders.

\subsubsection{Dough Preparation}

Powdered sugar and corn oil were creamed in Braun Mixer with a flat beater for 2 minutes at $6 \mathrm{rpm}$. Water containing sodium chloride, ammonium bicarbonate and rose oil was added to the cream and mixed for 5 minutes at $125 \mathrm{rpm}$ to obtain a homogenous cream. Thereafter flour was added slowly to the above cream and was mixed for 2 minutes at 60 rpm to obtain biscuit dough (Saba, 1997).

Table 1. Biscuit formula*

\begin{tabular}{|c|c|}
\hline Ingredients & Amount (g.) \\
\hline Wheat flour (72\% extraction) & 100.00 \\
\hline Powdered sugar & 25.00 \\
\hline Corn oil & 15.00 \\
\hline Sodium chloride & 1.00 \\
\hline Ammonium carbonate & 1.00 \\
\hline Rose oil & 0.01 (one drop) \\
\hline Water & 20.00 \\
\hline * Saba (1997).
\end{tabular}

\subsubsection{Preparation of Biscuit}

The dough was sheeted to a thickness of about $3 \mathrm{~mm}$ using Atlas Brand rolling machine. The sheeted dough was cut into round shape using a $45 \mathrm{~mm}$ diameter cutter and baked on an aluminium tray in an electric oven at $180^{\circ} \mathrm{C}$ for 6 minutes. The biscuit was cooled for 30 minutes, packed in polyethylene bags stored under desiccation (Vatsala and Hardias Rao, 1991, and Manohar and Rao, 1997).

\subsubsection{Preparation of Different Blends of Biscuits}

Blends of biscuits were prepared using wheat flour $72 \%$ extraction rate as control or those which substituted with $10 \%$ of Tangerine peel powder, $10 \%$ Abo-Sora orange peel powder, $10 \%$ Baladi orange peel powder, and 10\% Baladi lemon peel powder.

\section{Methods}

\subsection{Physical Evaluation of Biscuits}

Biscuits were evaluated for height $(\mathrm{cm})$, width $(\mathrm{cm})$, spread ratio and spread factor. Five biscuits were used for the evaluations from each of the five studied biscuits and averages were recorded. The spread ratio and spread factor were calculated according to Manohar and Rao (1997) using the following equations:

$$
\begin{gathered}
\text { Spread ratio }=\frac{\text { Width }}{\text { Height }} \\
\text { Spread factor }=\frac{\text { Spread ratio of sample }}{\text { Spread ratio of control }}
\end{gathered}
$$

\subsection{Sensory Evaluation of Biscuits:}

Sensory evaluation for the color, texture, taste, odor and overall acceptability were done in order to determine consumer acceptability. A numerical hedonic scale ranging from 1 to 10 ( 1 is very bad and 10 for excellent) was used for sensory evaluation (Larmond, 1977). Ten experienced judges participated in the test. 


\subsection{Proximate Chemical Composition}

Moisture, protein, crude fibers and ash contents were determined according to the method described in the AOAC (1997). Fat content was determined as the ether extract according to AOCS (1994). Total carbohydrates were calculated by difference according to Pellet and Sossy (1970). All determinations were performed in triplicates and the means were reported. The caloric value was calculated using values of $4 \mathrm{k} . c a l / g$. of protein, $4 \mathrm{k} . c a l / g$. of carbohydrate and 9 k.cal/g. of fat according to Livesy (1995).

\subsection{Determination of Mineral Contents}

The minerals contents i.e. (sodium, potassium, magnesium, calcium, iron, copper, manganese and phosphorus of wheat biscuits and fortified wheat biscuits with citrus peels powder were determined according to the methods described in AOAC (1997). The samples were wet acid digested using a nitric acid and perchloric acid mixture $\left(\mathrm{HNO}_{3}\right.$, $\mathrm{HCLO}_{4}, 2: 1 \mathrm{v} / \mathrm{v}$ ). The amounts of iron, copper, and manganese in the digested sample were determined using a GBC Atomic Absorption 906 A as described in AOAC (1997). Sodium and potassium were determined by flame photometer 410. Calcium and magnesium were determined using Double Beam Atomic Absorption. Phosphorus was determined according to the method described in A.O.A.C.
(1997).

\section{Results and Discussion}

\subsection{Physical Characteristics of Biscuits}

Citrus peels had been considered as a functional food supplement in certain good products because they are reckoned as a good source of dietary fibers, volatile oils, phenolic compounds, minerals and vitamins.

The mean values of physical characteristics of wheat biscuit and fortified wheat biscuits with citrus peels powder are presented in Table (2) and Figures 1-5. The data recorded a gradual increment of spread ratio of all fortified biscuits with all the four studied citrus peels powders ranging from 2.72 to 2.92 for $10 \%$ Tangerine peel powder supplemented biscuits and 10\% Abo-Sora orange peel powder supplemented biscuits. Considering the spread factor of control biscuits (100\% wheat flour-72\% extraction biscuits) as 100 , results given in Table (2) indicated that it increased to 104.00 , $111.00,110.00$ and 108.000; for $10 \%$ Tangerine peel powder supplemented biscuits, $10 \%$ Abo-Sora orange peel powder supplemented biscuits, $10 \%$ Baladi orange peel powder supplemented biscuits; and Baladi lemon peel powder supplemented biscuits; respectively.

Table 2. Physical characteristics of $100 \%$ wheat flour $-72 \%$ extraction biscuits (control) and wheat flour biscuits supplemented with $10 \%$ citrus peels powders

\begin{tabular}{|c|c|c|c|c|}
\hline Biscuit samples & Width $^{\mathrm{a}}(\mathrm{cm})$ & Thickness $^{\mathrm{b}}(\mathrm{cm})$ & Spread ratio $^{\mathrm{c}}$ & Spread factor $^{\mathrm{d}}$ \\
\hline $100 \%$ wheat flour $-72 \%$ extraction biscuits (control) & 3.24 & 1.24 & 2.62 & 100.00 \\
\hline $10 \%$ Tangerine peel powder supplemented biscuits & 3.22 & 1.20 & 2.72 & 104.00 \\
\hline $10 \%$ Abo-Sora orange peel powder supplemented biscuits & 3.36 & 1.18 & 2.92 & 111.00 \\
\hline $10 \%$ Baladi orange peel powder supplemented biscuits & 3.38 & 1.18 & 2.89 & 110.00 \\
\hline $10 \%$ Baladi lemon peel powder supplemented biscuits & 3.16 & 1.12 & 2.84 & 108.00 \\
\hline
\end{tabular}

a width of 5 biscuits in series.

$\mathrm{b}$ thickness of 5 biscuits in series.

c width/thickness

d $\frac{\text { Spread ratio of sample }}{\text { Spread }}$

Spread ratio of control

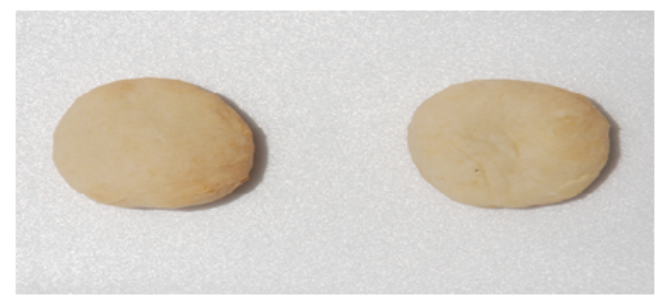

Figure 1. $100 \%$ Wheat flour- $72 \%$ extraction biscuits

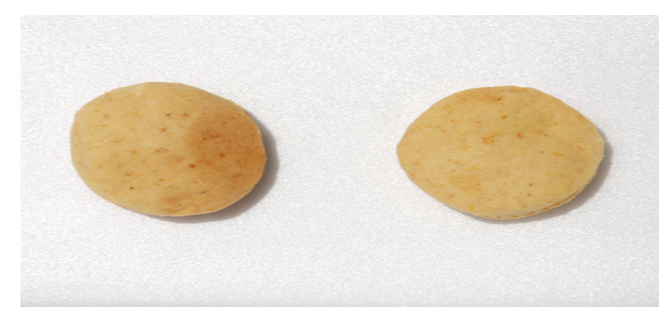

Figure 2. $10 \%$ Tangerine peel powder supplemented biscuits

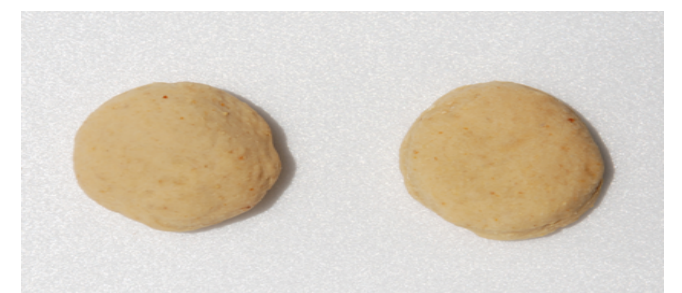

Figure 3. $10 \%$ Abo-Sora orange peel powder supplemented biscuits

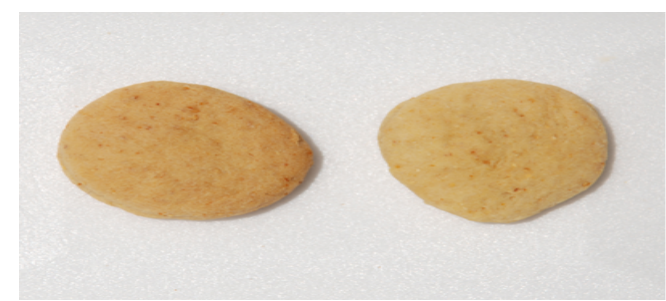

Figure 4. $10 \%$ Baladi orange peel powder supplemented biscuits 


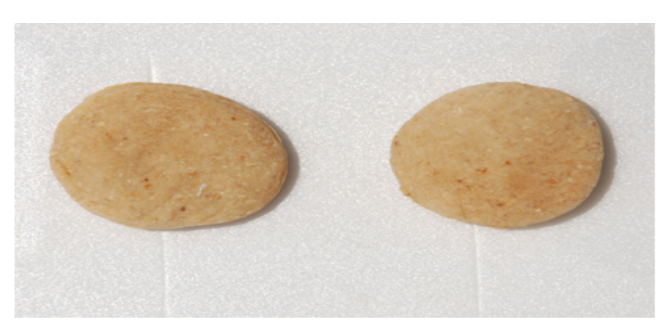

Figure 5. $10 \%$ Baladi lemon peel powder supplemented biscuits

\subsection{Sensory Characteristics of Biscuits}

The sensory characteristics of the studied wheat biscuits as influenced by the incorporation of $10 \%$ Tangerine peel powder, $10 \%$ Abo-Sora orange peel powder, $10 \%$ Baladi orange peel powder, and $10 \%$ Baladi lemon peel powder are outlined in table (3). The data revealed that all fortified biscuits with $10 \%$ of the four studied citrus peels powders improved all studied sensory characteristics in all the studied biscuit samples. However, the best scores of all studied sensory characteristics were recorded for $10 \%$ Baladi orange peel powder supplemented biscuits and 10\% Abo-Sora orange peel powder supplemented biscuits.

Therefore, both $10 \%$ Baladi orange peel powder supplemented biscuits and 10\% Abo-Sora orange peel powder supplemented biscuits could be recommended to be produced as biscuits with good quality acceptable sensory quality attributes. Likewise, on the basis of such result further analysis of gross chemical composition and mineral composition of the four fortified wheat biscuits with $10 \%$ of the four studied citrus peel powders were evaluated and were compared with the control biscuits $(100 \%$ wheat flour $-72 \%$ extraction biscuits).

\subsection{Gross Chemical Composition of Biscuits}

The mean value of gross chemical composition and caloric value of wheat biscuits and fortified wheat biscuits with citrus peel powders are given in table (4). The data revealed that $10 \%$ incorporation of citrus peels powders in wheat flour biscuits increased crude protein, crude fat contents as well as crude fiber, moisture contents and caloric value. However, such supplementation decreased carbohydrate content.

However, $10 \%$ Baladi lemon peel powder supplemented wheat biscuits recorded the highest crude fat (16.99\%), crude fiber $(1.67 \%)$, moisture content $(7.50 \%)$ and caloric value (472.27 k.cal/100g) as well. Meanwhile, it recorded the least carbohydrate content (72.84\%). 10\% Tangerine peel powder supplemented biscuits the recorded least caloric value $(431.96 \mathrm{k.cal} / 100 \mathrm{~g})$ on dry weight basis. Such data are in good agreement with those previously reported by Steinmetz and Potter (1996), Youssef (2007), Donalson (2004), Archibald (2005) and Gonzalez-Molina et al. (2010).

On the other hand, the high increment in crude fibers recorded in the four studied wheat biscuits fortified with $10 \%$ citrus peels powders are in good accordance with Sugimura (2002), Bobroff (2002), De Vries (2004), and Archibald (2005).

\subsection{Minerals Composition of Biscuits}

The mean values of minerals composition of wheat biscuits, and fortified wheat biscuits with citrus peel powders are outlined in table (5). The data revealed that $10 \%$ Abo-Sora orange peel powder supplemented wheat biscuits, and $10 \%$ Baladi lemon peel powder supplemented wheat biscuits had the highest $\mathrm{Ca}$; and $\mathrm{Na}$ and $\mathrm{K}$ contents, respectively. Meanwhile, the latter 10\% Baladi lemon peel recorded in addition the highest $\mathrm{P}$ content among all studied biscuits on dry weight basis. Such data coincide with Cohen et al. (1984), Sulamyn et al. (1990), and Youssef (2007).

Table 3. Sensory characteristics of $100 \%$ wheat flour $-72 \%$ extraction biscuits (control) and wheat flour biscuits supplemented with $10 \%$ citrus peels powders*

\begin{tabular}{|c|c|c|c|c|c|}
\hline Biscuit samples & Color & Texture & Taste & Odor & Overall acceptability \\
\hline $100 \%$ wheat flour - 72\% extraction biscuits (control) & 7.00 & 7.50 & 7.00 & 8.00 & 7.50 \\
\hline $10 \%$ Tangerine peel powder supplemented biscuits & 8.00 & 8.00 & 7.80 & 8.00 & 7.90 \\
\hline $10 \%$ Abo-Sora orange peel powder supplemented biscuits & 8.00 & 8.20 & 8.00 & 8.20 & 8.10 \\
\hline $10 \%$ Baladi orange peel powder supplemented biscuits & 8.00 & 8.00 & 8.00 & 8.00 & 8.00 \\
\hline $10 \%$ Baladi lemon peel powder supplemented biscuits & 8.00 & 7.50 & 7.50 & 8.00 & 7.75 \\
\hline
\end{tabular}

* Mean of ten replicates.

Table 4. Gross chemical composition and caloric value of wheat biscuits and fortified wheat biscuits with citrus peels powders (on dry weight basis)*

\begin{tabular}{|c|c|c|c|c|c|}
\hline \multirow{2}{*}{ Constituents \% } & \multicolumn{5}{|c|}{ Types of biscuits } \\
\cline { 2 - 6 } & WB $^{1}$ & WBFTPP $^{2}$ & WBFAPP & WBFOPP $^{3}$ & WBFLPP $^{5}$ \\
\hline Crude protein & 7.01 & 7.69 & 7.69 & 7.44 & 7.00 \\
\hline Crude fat & 11.98 & 16.05 & 14.69 & 1.00 & 1.99 \\
\hline Ash & 1.50 & 1.50 & 1.50 & 1.21 & 1.50 \\
\hline Crude fiber & 0.19 & 0.66 & 75.31 & 74.65 & 72.84 \\
\hline Carbohydrate** & 79.23 & 74.19 & 464.21 & 469.66 & 472.27 \\
\hline Caloric value (k.cal/100g) & 452.78 & 431.96 & 6.40 & 6.40 & 7.50 \\
\hline Moisture & 5.30 & 6.40 & & & \\
\hline
\end{tabular}

* Mean of three replicates.

$1-100 \%$ wheat flour- $72 \%$ extraction biscuits (control)

2- $10 \%$ Tangerine peel powder supplemented biscuits.

3- $10 \%$ Abo-Sora orange peel powder supplemented wheat biscuits.

4- $10 \%$ Baladi orange peel powder supplemented wheat biscuits.

5- $10 \%$ Baladi lemon peel powder supplemented wheat biscuits.

** Calculated by difference. 
Table 5. Mineral composition of wheat biscuits and fortified wheat biscuits with citrus peels powders (on dry weight basis)*

\begin{tabular}{|c|c|c|c|c|c|c|c|c|}
\hline \multirow{3}{*}{ Type of biscuits } & \multicolumn{8}{|c|}{ Minerals content } \\
\hline & $\mathrm{Fe}$ & $\mathrm{Mn}$ & $\mathrm{Cu}$ & $\mathrm{Ca}$ & $\mathrm{Mg}$ & $\mathrm{Na}$ & $\mathrm{K}$ & $P$ \\
\hline & \multicolumn{3}{|c|}{ ppm } & \multicolumn{5}{|c|}{$\%$} \\
\hline $\mathrm{WB}^{1}$ & 30.33 & 1.65 & 3.40 & 0.02 & 0.02 & 0.24 & 0.11 & 0.18 \\
\hline WBFTPP $^{2}$ & 17.70 & 1.03 & 1.33 & 0.01 & 0.01 & 0.28 & 0.16 & 0.18 \\
\hline WBFAPP $^{3}$ & 18.48 & 0.88 & 1.40 & 0.08 & 0.01 & 0.24 & 0.14 & 0.18 \\
\hline WBFOPP $^{4}$ & 19.23 & 0.10 & 2.38 & 0.05 & 0.02 & 0.26 & 0.17 & 0.17 \\
\hline WBFLPP $^{5}$ & 27.43 & 0.98 & 2.38 & 0.04 & 0.02 & 0.41 & 0.23 & 0.22 \\
\hline
\end{tabular}

* Mean of three replicates.

$1-100 \%$ wheat flour- $72 \%$ extraction biscuits (control).

$2-10 \%$ Tangerine peel powder supplemented biscuits.

3- $10 \%$ Abo-Sora orange peel powder supplemented wheat biscuits.

4- $10 \%$ Baladi orange peel powder supplemented wheat biscuits.

5- $10 \%$ Baladi lemon peel powder supplemented wheat biscuits.

In conclusion, the four studied wheat biscuits fortified with $10 \%$ citrus peel powders proved to be nutritious functional and healthful foods. Moreover, they could be recommended for caloric reduced diets for obese and over-weight persons especially $10 \%$ Tangerine peel powder supplemented wheat biscuits. Likewise, the rather relative low carbohydrate content in the four studied wheat biscuits fortified with $10 \%$ citrus peels powders could be recommended for the diet regimen of diabetic persons.

\section{REFERENCES}

[1] Abdel-Galil, M.A. (1998). Physicochemical studies on the essential oils of Baladi orange and mandarin. Egyptian J. of Agricultural Research. Volume 23, No. 4, 1009-1018

[2] Abdel-Raouf, M.M. (1997). Production and evaluation of some citrus low terpenes essential oils. M.Sc. Thesis, Faculty of Agriculture, Monoufia University

[3] AOAC (1997). Official Methods of Analysis. $16^{\text {th }}$ Ed., Association of Official Analytical Chemists. Arlington-Virginia, USA

[4] AOCS (1994). Official Methods of American Oil Chemists Society-Champaign. Illinois. USA

[5] Archibald, A. (2005). The definitive dietary fiber. Prepared Foods. March 2005

[6] Aumar, E.A. (1997). Biochemical studies on the essential oils of Baladi orange and mandarin. Egyptian J. of Horticulture. Volume 4, No. 2, 207-218

[7] Block, G., Patterson, B., and Subar, A. (1992). Fruit, vegetables and cancer prevention: a review of the epideminological evidence. Nutr. Cancer, 18:1-29

[8] Bobroff, L.B. (2002). Nutrition for health and fitness: Fiber in your diet. Sheet FCB 9130, a Series of the Department of Family, Youth and Community Sciences, Florida Cooperative Extension Service. Institute of Food and Agricultural Sciences, University of Florida

[9] Cohen, E., Sharon, R., Volman, L., Hoenig, R., and Saguy, I. (1984). Characteristics of Israeli citrus peel and citrus juice. J. of Food Science, Volume 49, Issue 4, 987-990

[10] De Vries, J. (2004). Dietary fiber. J. of AOAC International
[11] Donalson, M.S. (2004). Nutrition and cancer: a review of the evidence for anti-cancer diet. Nutr. Journal, 3 (1): 19, 1475-2891

[12] Eisa, A.I. (1995). Studies on the composition of lemon and mandarin peel essential oils and their utilization as anti-pathogenic bacteria agents. Monoufia J. of Agricultural Research. Volume 20, No. 1, 1-14

[13] El-Shemy, M.G., Abd-Allah, A.M. and Farag, S.E. (1990). Relation between irradiation doses and browning, oxidative enzymes and phenols of grapefruits. Annals of Agricultural Science, Spec. Issue, 221-233

[14] Gonzalez-Molina, E., Dominguez-Perles, R., Moreno, D.A., and Garcia-Viguera, C. (2010). Natural bioactive compounds of citrus lemon for food and health. J. of Pharmaceutical and Biomedical Analysis, Volume 51, Issue 2, 327-340

[15] Haggag, E.G. (1992). A pharmacognostical study of citrus aurantifolia swingle and citrus limonia obsect (family: Rutaceae). M.Sc. Thesis, Faculty of Pharmacy. Cairo University

[16] Kamel, H.A. (1990). Effect of gamma irradiation on certain citrus fruits. Ph.D. Thesis, Faculty of Agriculture, Cairo University

[17] Larmond, E. (1977). Laboratory Methods for Sensory Evaluation of Food. Canadian Government Publishing Center. Ottawa

[18] Liu, Y., Ahmad, H., Luo, Y., Gardina, D.T., Guasekera, R.S., Mc Keehan, W.L. and Patil, B.S. (2001). Citrus pectin: Characterization and inhibitory effect on fiberblast growth factor-receptor interaction. J. Agric. Food Chem., 49 (6), 3051-3057

[19] Livesy, G. (1995). Metabolizable energy of macro-nutrients. Am. J. Clin. Nutr. 62 (Suppl.) - 11355-11425

[20] Manohar, R.S. and Rao, P.H. (1997). Effect of mixing period and additives on the rheological characteristics of dough and quality of biscuit. J. of Cereal Sci., 25: 197-206

[21] Patil, B., Jayaprakasha, G.K., and Harris, E.D. (2010). Impact of citrus limonoids on human health. Natural Bioactive compounds on human health, Vol. 51, Issue 2, 327-345

[22] Pellet, P.I. and Sossy, S. (1970). Food Composition Tables for Use in the Middle East. American University of Beirut. Beirut - Lebanon

[23] Saba, N.H. (1997). Culinary is Science and Art. P. 685. Dar El-Maaref-Cairo (In Arabic) 
[24] Steinmetz, K.A. and Potter, J.D. (1996). Vegetables, fruits and cancer prevention: a review. J. Am. Diet Assoc., 96: $1027-1039$

[25] Sugimura, T. (2002). Food and Cancer, Toxicology, Dec. 27, 181-182: 17-21

[26] Sulamyn, A., Abdel-Lattif, A. and El-Zughbi, M. (1990). Effect of different methods of extraction on the physico-chemical properties of Egyptian summer orange peel oils. Egyptian J. of Applied Science, Volume 5, No. 78, 300-309
[27] Vatsala, C.N., and Haridas Rao, P. (1991). Studies on invert sugar for use in biscuits. J. Food Sci. and Techn. 28: 149-152

[28] Youssef, M.K.E. (2007). Foods that fight cancer. Proceedings of the six ${ }^{\text {th }}$ Conference of Woman and Scientific Research \& Development in Upper Egypt. 17-19 April 2007, p. 213-228. Assiut University 